\title{
AZ IDŐJÁRÁSI VISZONYOK HATÁSA MÉZGÁS ÉGER ÉS KOCSÁNYOS TÖLGY ÁLLOMÁNYOK NÖVEKEDÉSÉRE TALAJVÍZHÁZTARTÁS JAVÍTÁSÁT CÉLZÓ BEAVATKOZÁSOK MELLETT
}

\author{
Garamszegi Balázs ${ }^{1}$, Nagy-Khell Melinda', Farkas Máté1 és Nagy László ${ }^{2}$ \\ ${ }^{1}$ NAIK Erdészeti Tudományos Intézet, Ökológiai és Erdőmüvelési Osztály, Sárvár \\ ${ }^{2}$ NAIK Erdészeti Tudományos Intézet, Nemesitési Osztály, Sárvár
}

\begin{abstract}
Kivonat
Az érintett erdőterületek vízellátásának javitását célzó KASZÓ-LIFE projekt monitoring feladataihoz kapcsolódóan évgyürüelemzést folytattunk mézgás éger (Alnus glutinosa) és kocsányos tölgy (Quercus robur) mintaterületeken. A vizsgálat elsődleges célja annak kimutatása volt, hogy a müszaki beavatkozások segítségével visszaduzzasztott és kiegyensúlyozottabb évközi m enetủ talajvízszint hatása miként jelenik meg a fák növekedésében, illetve, hogy az évgyürüszélességek a megváltozott körülmények között milyen érzékenyen reagálnak egy-egy aszályosabb év időjárási szélsőségeire. Az előzetes vizsgálatok kimutatták, hogy az éger állományok növekedése, az égeres területeken lévő magasabb talajvíztükör ellenére, jóval szorosabb összefüggést mutat a meteorológiai változókkal - elsősorban a nyári csapadékkal és relativ páratartalommal -, mint a tölgyeseké. A beavatkozások pozitiv hatását mutathatja, hogy a SPEI aszályindex és a gyenge éves átmérőnövedékek által kijelölt, 2000 utáni legaszályosabb évek közül, a beavatkozásokat követő 2017. évben az érintett éger állományok növekedésének csökkenése jóval kisebb volt a kontroll parcelláéhoz képest, noha azt megelőzően minden esetben fordított tendencia mutatkozott. Ennek ellenére, ebben az évben az összes vizsgált állomány növekedésmenete nagyobb visszaesést mutatott, mint amekkorát a korábbi évek tapasztalata alapján az időjárási körülmények indokolhattak volna, ami egyben a sorozatos aszályok és a kedvezőtlen éghajlati trendek hatását jelezheti még az ezeket mérséklő beavatkozások mellett is.
\end{abstract}

Kulcsszavak: KASZÓ-LIFE, talajvíz, aszály, mézgás éger, kocsányos tölgy, évgyürüelemzés

\section{IMPACT OF WEATHER CONDITIONS ON THE INTERANNUAL GROWTH CHARACTERISTICS OF ALDER AND OAK STANDS WITH IMPROVED GROUNDWATER-MANAGEMENT}

\begin{abstract}
Tree ring analysis in common alder (Alnus glutinosa) and pedunculate oak (Quercus robur) stands were carried out as a part of the monitoring tasks related to the KASZÓ-LIFE project, which targeted to improve the groundwater supply of the project area. Aims of the research were to identify benefits of the increased groundwater level and its more balanced
\end{abstract}


interannual course due to the technical interventions in the growth of the sample trees. A specific focal point was to assess the sensitivity of the annual increments to the severe weather events like droughts under the changed conditions. The preliminary results reveal a much stronger relationship of alder growth with climate (first of all, with summer rainfall and mean relative humidity) than in case of oak, even when considering the generally higher groundwater level of alder stands. Regarding the benefits of the technical interventions, a series of severe drought years after 2000 , selected by the 6-month SPEI drought index and decrease in alder increments indicate that following the actions, growth decrease of alder stands were significantly lower than the rate at the control site in 2017, though a reverse tendency was common during all the previous drought periods. However, the average increment decline of all investigated stands was much stronger in this year, than it could be predicted by the weather conditions based on the growth-climate relationships dating back to the previous decades, giving a possible evidence of unfavorable climatic trends and recurrent drought periods, even parallel with the mitigating actions.

Keywords: KASZÓ-LIFE, groundwater, drought, common alder, pedunculate oak, tree-ring analysis

\section{BEVEZETÉS}

A talajvíz elérhetősége a síkvidéki területek egyik legfontosabb élő- és termőhely-meghatározó tényezője, így ezeket a régiókat a talajvízszint magasságának kérdése elsődlegesen érinti napjaink összetett környezeti problémái közül, csakúgy az itt található erdeink, mint a mezőgazdasági termelés tekintetében. A változó éghajlat, különösen az aszályos időszakok gyakoriságának növekedése jelentős hatással bírhat a talajvízszint csökkenésére, mely számos helyen okozhat nehézségeket a terület vízellátását illetően (Garamhegyi et al 2018).

A talajvízháztartás állapota és a talajvízszint süllyedése így többek között erősen befolyásolhatja az olyan, jó vízellátottságú termőhelyekhez kötődő erdők egészségi állapotát és növekedését, mint a síkvidéki mézgás égeres (Alnus glutinosa) és kocsányos tölgyes (Quercus robur) állományok, szélsőséges esetben akár jelentős mortalitást is okozva (Levanič 1993, Stojanović et al 2015).

$A z$ „Enyves éger (Alnus glutinosa) és magas kőris (Fraxinus excelsior) alkotta ligeterdők (Alno-Padion, Alnion incanae, Salicion albae) helyreállítása és megőrzése Kaszó területén" című, az Európai Unió LIFE+ programjának keretében megvalósuló projekt (KASZÓ-LIFE) célja a belső-somogyi Szentai-erdő csökkenő talajvízszint (DDKÖVÍZIG 2011) következtében degradálódó élőhelyeinek helyreállítása és megőrzése, a terület vízellátásának javításával. A 2015/2016 telén elvégzett műszaki beavatkozások régi víztározók bővítésével és új tavak kialakításával 8,7 ha új vízfelületet, 88 ezer $\mathrm{m}^{3}$ többletkapacitást eredményeztek, a vízfolyások mentén, 15 fkm hosszon 123 db mederborda kihelyezése segíti a csapadékvíz hosszabb ideig területen tartását, ezen kívül a Baláta-tó vízszint-szabályozása is lehetővé vált.

A projekt és az ennek keretei között megvalósult vízgazdálkodási beavatkozások monitoring és kutatási feladatai között szerepelt az érintett erdőállományok növekedésének vizsgálata évgyürü-elemzési módszerek segítségével. A vizsgálatok során megpróbáltunk választ keresni arra, hogy a vízháztartás javítását célzó beavatkozások hogyan érinthetik a társulásokat ökológiai és gazdasági szempontból meghatározó fás vegetáció növekedését.

\section{ANYAG ÉS MÓDSZER}

Kaszó, Somogyszob és Szenta községhatárok erdőrészleteiben (kb. É.sz. 46,32 ${ }^{\circ}$ K.h. 17,22 ${ }^{\circ}$ t.sz.f. 150 m) kijelölt mézgás éger és kocsányos tölgy monitoring területek mintavételeit 2018 februárjában végeztük el, melynek során Pressler növedékfúró segítségével a 18 mintaterület mindegyikén 10, a területre és az (uralkodó) átmérő-osztályra reprezentatív, sorszámozott fából vettünk növedékcsapot, egyedenként 2-2 sugár 
mentén. A mintaterületek hidrológiai viszonyait az időszakos vagy állandó vízhatás jellemzi, homokon képződött, mély termőrétegü típusos réti, illetve az időszakos vízhatás mellett megjelenő Ramann-féle barnaföld genetikai talajtípusok mellett. A mézgás éger állományok jellemzően elegyetlenek, a kocsányos tölgyesekben esetenként 5-10\% elegyarány mellett megjelenik a cser (Quercus cerris) és a gyertyán (Carpinus betulus), illetve az alacsonyabb térszínek mellett jelentős égeres foltok találhatóak, mely azonban a mintavételi területeket nem érintette.

Jelen tanulmányban 5 éger és 4 tölgy parcella (fafajonként 1-1 kontrollal) adatai kerültek feldolgozásra, melyek kiválasztása az állományok kora, illetve a terepi felvételek és a termőhelyi háttérinformációk figyelembevételével történt. A kontroll állományok a KASZÓ-LIFE projektterületen kívül helyezkedtek el, míg a projektterületi állományok esetén a müszaki beavatkozások hatása már várhatóan az első években is érzékelhető volt (LIFE akció). A mintaelőkészítést, a növedékcsapok polírozását és nagyfelbontású (1800 dpi) szkennelését követően a mérések WinDENDRO szoftver (Regent Instruments, 2017) segítségével, az adatok feldolgozása, kiértékelése pedig az $\mathrm{R}$ statisztikai programcsomaggal ( $\mathrm{R}$ Core Team, 2017) történtek.

A növekedési idősorok (múltbeli) klimatikus érzékenységét az egyedszintű növekedési válaszok vizsgálatán (Buras et al 2018) alapuló korreláció-analízissel vizsgáltuk az 1981-2010-es időszakra, a növekedési és az azt megelőző év hónapjaira külön-külön. Ehhez az évgyürüszélességek polinomiális simítógörbével trendmentesített index adatsorát és a CARPATCLIM adatbázis (Szalai et al 2013) sürü állomáshálózati mérések alapján interpolált, 2010-ig elérhető havi átlaghőmérséklet, csapadékösszeg és átlagos relatív páratartalom idősorait használtuk fel. Az egyedszintű vizsgálatoknak köszönhetően a korrelációs kapcsolat átlagos erősségén túl annak egyedek közti változékonyságáról is képet kaphattunk. Azokra a meteorológiai változókra, ahol a korrelációs kapcsolat szignifikánsnak bizonyult (együtthatók mediánja $p<0,05)$, egy, az átlagos növekedési indexre vonatkozó többváltozós lineáris modell került felállításra, melynek kiterjesztésével, a kapott együtthatókat figyelembe véve, becsültük a növekedést a projekt keretei között telepített automata meteorológiai állomás (Boreas Kft., 2014) végzett helyi mérések 2015-2017-es időszakára is.

Végezetül a teljes vizsgálati időtartamra rendelkezésre álló, nagytérségü, interpolált éghajlati adatokból (E-OBS $0,25^{\circ}$ hőmérséklet, GPCC monitoring 0,5 csapadék; Haylock et al 2008, Schneider et al 2015), a potenciális evapotranspiráció figyelembe vételével számolt 6 hónapos júliusi SPEI aszályindex (VicenteSerrano et al 2010) negatív értékei által kijelölt, 2000 utáni legaszályosabb évek növekedési viszonyai kerültek összehasonlításra az égeres mintaterületek méréseire, illetve a klimatikus változókkal modellezett relatív növekedési értékekre. A SPEI index használatát az erdészeti irodalomban elterjedtebb indexek helyett az indokolta, hogy a bemenő adatok hosszabb időablaka részben magába foglalja a téli és kora tavaszi talajvízfeltöltődési időszakot is, mindemellett mégis jelentős súlyt fektet a vegetációs időszak kezdeti, fő növekedési időszaki meteorológiai viszonyokra.

\section{EREDMÉNYEK}

A mérések tanúsága szerint a vizsgált állományok átlagos kora 50-60 év között volt, a feldolgozott égeresek közül egy idősebb (közel 90 éves), illetve a kocsányos tölgyesek közül egy fiatalabb (kb. 25 éves) állomány bővítette a vizsgált mintaterületek korbeli eloszlását (1. ábra). Az égerek, a tölgyekhez képest, az erőteljes korai vastagsági növekedés után az évgyürüszélességek fokozatos csökkenését, míg a tölgyek kevésbé markáns és egyben időben kiegyenlítettebb növekedésmenetet mutattak. 


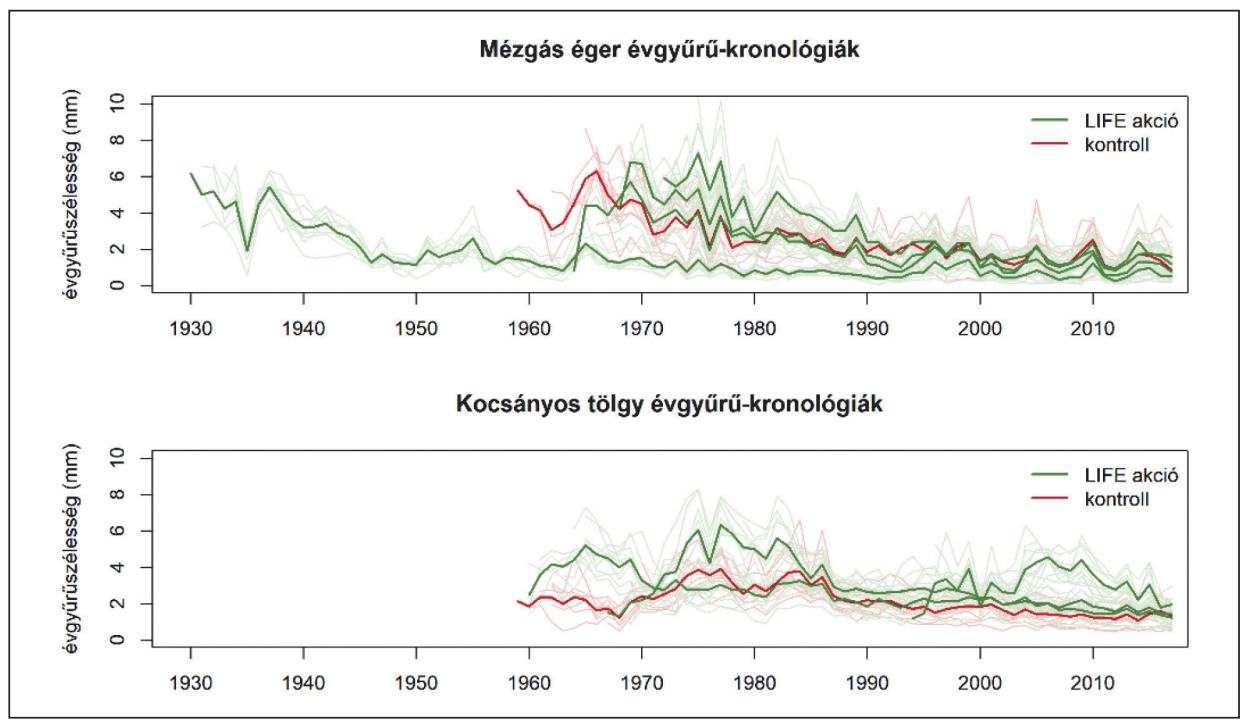

1. ábra: Az évgyürüszélesség mérések eredményei a két vizsgált fafajra, vastaggal a mintaterületi átlagok

Figure 1: Ring-width chronologies of the selected five alder (Alnus glutinosa; top) and four oak (Quercus robur; bottom) monitoring plots with one control parcel for each species (in red); bold lines represent the site means

A trendmentesített egyedszintü évgyürü-kronológiák korrelációs kapcsolatát a három kiválasztott meteorológiai változóval box-diagramokon ábrázoltuk (2. ábra).

A diagramok tanúsága szerint az égerek növekedése jóval erősebb és egyértelmübb kapcsolatban állt az időjárás évenkénti alakulásával a mintaterületeken, mint a tölgyeké, mindenekelőtt a csapadék és páratartalom változókra. A legmagasabb korrelációs együtthatók mindkét fafaj esetén a júliusi átlagos relatív páratartalommal adódtak (tölgy medián: 0,36, éger medián: 0,54). A kocsányos tölgy esetében egyedül ez a változó mutatott szignifikáns összefüggést, míg az éger növedékadatokkal a januári és az áprilistól egészen szeptemberig tartó páratartalom értékek, valamint az áprilisi, májusi, júniusi és augusztusi csapadékösszegek is. A korrelációs eredményeket és a növekedésmenet nagyobb évközi változékonyságát figyelembe véve a továbbiakban elsősorban az égerek növekedését vizsgáljuk. A fentebb felsorolt, szignifikáns kapcsolatot mutató klimatikus változókra épülő lineáris modell az égeresek átlagos éves növekedési index idősorának varianciáját $85 \%$-ban fedte le (3. ábra).

Az égerek növekedésének 2000-es évek utáni jelentős relatív ingadozásai egyben jó összefüggést mutatnak a SPEl aszályindex 6 hónapra számolt júliusi értékeivel, csakúgy mint a júliusi átlagos relatív páratartalommal (4. ábra), mely meteorológiai változóval egyben a korrelációs kapcsolat is a legerősebbnek bizonyult. Az éghajlati idősorok tanúsága szerint az utolsó két évtized legaszályosabb évei 2003., 2007., 2012. és 2017. voltak, melyek egyben az időszak négy legkisebb növekedésű évének felelnek meg (vö. 3. ábra). Az aszályérzékenység esetleges változásának kimutatására a felsorolt évek növekedési viszonyaira külön összehasonlítást végeztük.

A 2000 után kiválasztott négy kis növekedésű év során minden esetben a többletvízhatástól kevésbé érintett és így vélhetően mélyebb gyökérzónájú kontroll állomány átlagos évgyürűszélessége volt nagyobb a négy feldolgozott mintaterület átlagos évi növedékéhez képest, kivéve a 2015-2016. évi beavatkozásokat követő 2017. évi aszály idején (5. ábra, bal oldal). A kontroll parcella átlagos évgyűrűszélessége 1,43 mm, míg a projektterületi 1,13 mm volt a 2000-2017-es időszakra. A változásokat még jobban mutatja az előző két évhez viszonyított relatív növedékcsökkenés, ahol a közel azonos értékeket 2017-re szignifikáns eltérés váltotta fel a projektterületről vett minták javára (5. ábra, jobb oldal), noha azok is alulmaradtak az erre az évre, a helyi meteorológiai mérésekkel modellezett, várt relatív növekedéshez képest. 


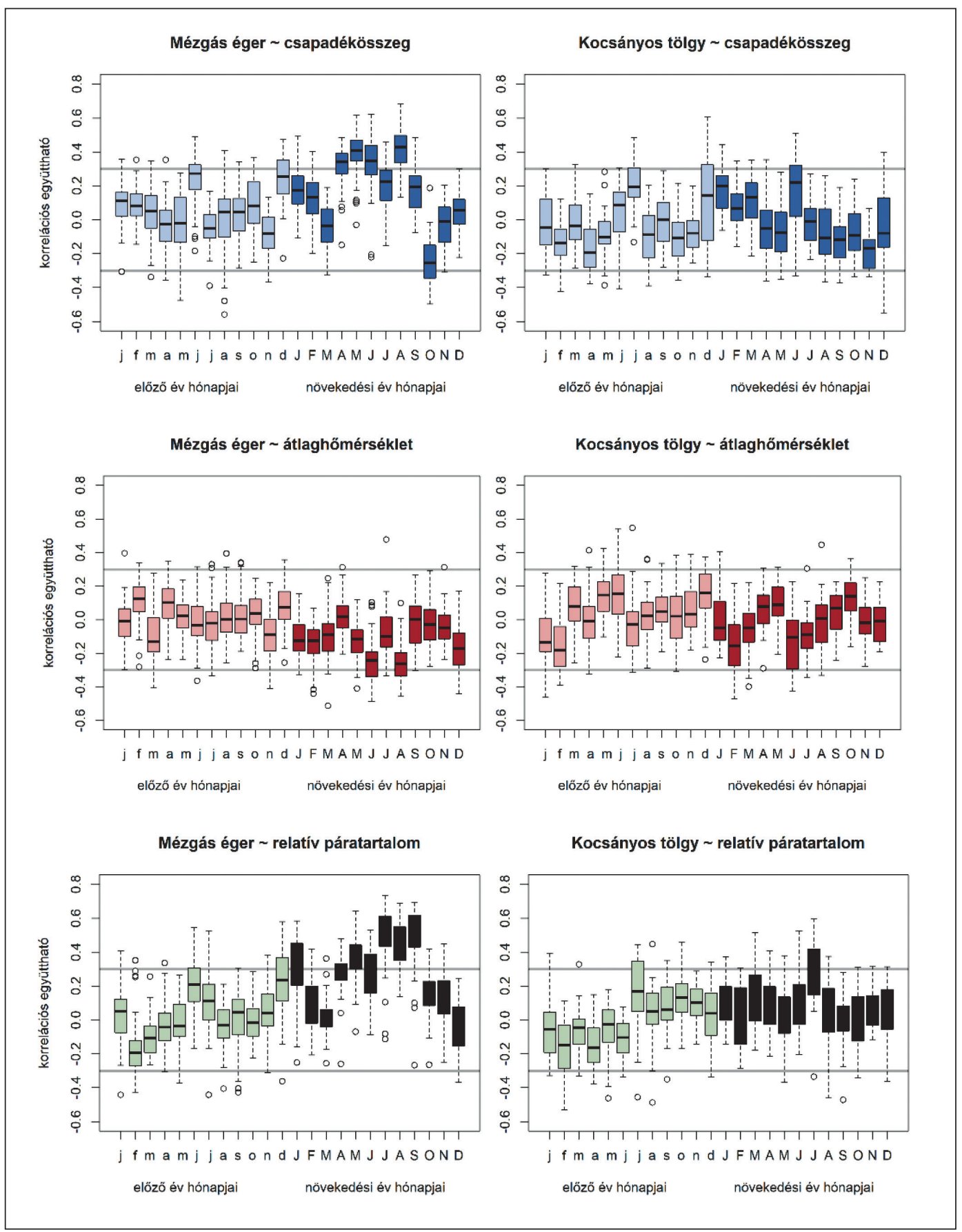

2. ábra: Havi meteorológiai változók és a trendmentesitett évgyürü-kronológiák közötti korreláció-vizsgálat eredményei (minimum, maximum és az interkvartilis tartomány a mediánnal; szürke vonal alattffelett: $p<0,05$ )

Figure 2: Results of the correlation analysis of detrended individual ring-width chronologies (alder: left; oak: right) with selected climatic variables (precipitation in blue, mean temperature in red and mean relative humidity in green) for the months of the previous and the growing year (minimum, maximum and interquartile range with median; above/below grey line: $p<0.05$ ) 


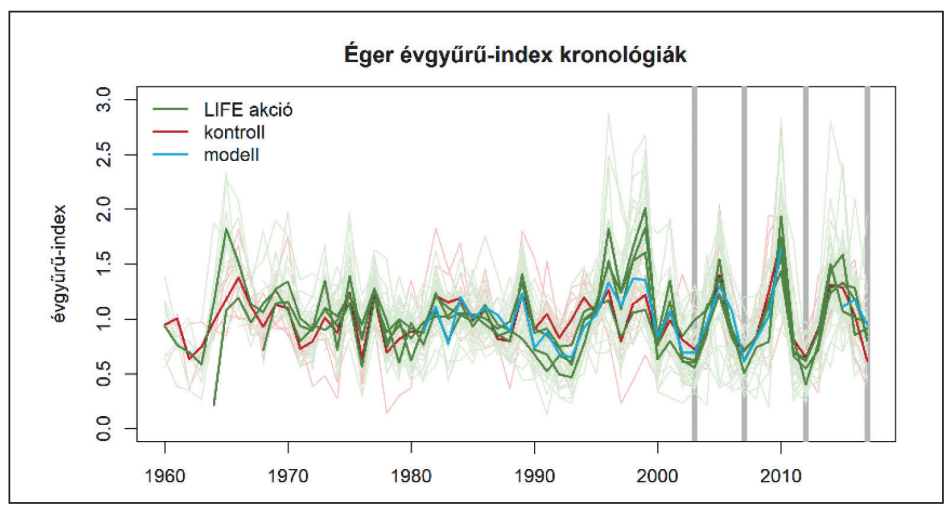

3. ábra: Trendmentesitett (index) éger évgyürü kronológiák és az átlagra vonatkozó, szignifikáns kapcsolatot mutató meteorológiai változókra épülő többváltozós lineáris modell $\left(R^{2}=0,85\right)$

Figure 3: Detrended alder ring-with series and the modeled mean chronology (blue line) of multiple linear regression $\left(R^{2}=0.85\right)$ based on climatic variables with significant relationship to annual growth

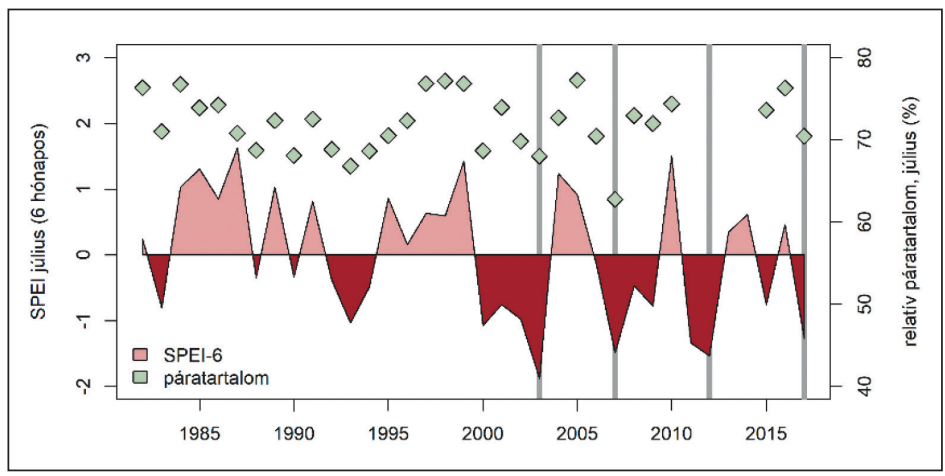

4. ábra: Az első félévi, 6 hónapos SPEI aszályindex nagytérségü rácsponti adatokra (E-OBS/GPCC) és az átlagos júliusi páratartalom értékek (CARPATCLIM: 1982-2010, helyi meteorológiai mérések: 2015-2017)

Figure 4: July SPEI (6-month) based on regional gridded climate data (E-OBS/GPCC) and July mean relative humidity (CARPATCLIM: 1982-2010; local data: 2015-2017); 2003, 2007, 2012 and 2017 were identified as years of severe drought

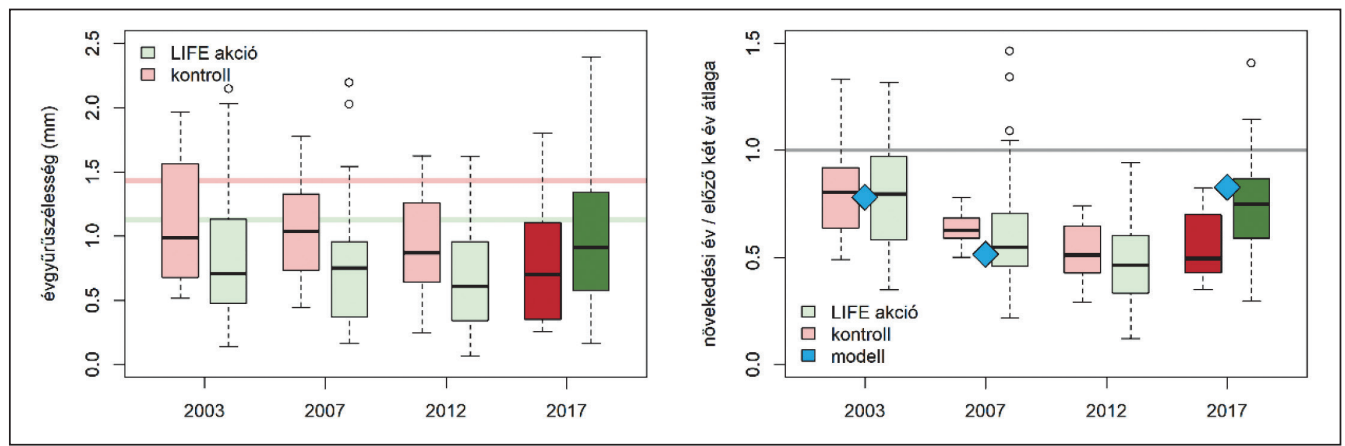

5. ábra: Évgyürüszélességek, vízszintes vonallal a 2000-2017. időszaki átlag (bal oldal), és a vastagsági növekedés előző két évtől vett relatív csökkenése a modellezett értékekkel (jobb oldal) a kiválasztott négy aszályos évben. A 2017-es év a müszaki beavatkozásokat követő állapotot mutat

Figure 5: Alder ring-widths during the selected four drought years comparing the project area and the control site (in red), horizontal lines represent 2000-2017 mean (left side); and relative growth decline compared to the previous 2 years, showing modeled values where available (right side). 2017 already faced improved groundwater conditions by the LIFE actions 


\section{MEGVITATÁS}

A vizsgált állománybeli fák jól követték az adott fafajokra elvárt növekedésmenetet (Gencsi \& Vancsura 1992, Claessens et al 2010). Az égerek évgyürüszélessége jóval erősebb kapcsolatot mutatott a meteorológiai változókkal a mintaterületeken, mint a tölgyeké, annak ellenére, hogy az égeres állományok alacsonyabb térszíneken, vízfolyások partján és általában magasabb talajvízszint mellett találhatók. A tölgyek éves növekedése valószínüleg a talajvízszint ingadozásaival állhat szorosabb kapcsolatban, bár más termőhelyi viszonyok mellett folytatott vizsgálatok az időjárás közvetlen hatását is erősebbnek itélték meg az általunk feltárt kapcsolatoknál, többletvízhatással különböző mértékben érintett, ártéri területek esetén is (Čater \& Levanič 2015, Stojanović et al 2015, Árvai et al 2018).

A fafajok növekedésének különböző fiziológiai sajátosságai, a gyökérzónájuk mélysége és ezzel összefüggésben a korrelációs vizsgálatok eredménye azt vetítették elöre, hogy a vízgazdálkodási beavatkozások hatásai rövid távon elsősorban az éger állományok növekedésének tekintetében vizsgálhatók. Az égerek környezeti változásokra, különösen a talajvízszint süllyedésére való, kocsányos tölgyesekénél nagyobb érzékenységét, korábbi vizsgálatok is igazolták (Levanič 1993). Növekedésük a környezeti változókkal jól modellezhetőnek bizonyult (vö. Laganis et al 2008), a relatív páratartalom és csapadék idősorokon alapuló többváltozós regresszió igen nagy pontossággal $\left(R^{2}=0,85\right)$ közelítette meg a mért relatív növekedésmenetet.

A környezeti változókra való nagyobb fokú érzékenység növekedésben való megjelenését az elmúlt két évtized legaszályosabb éveiben vizsgáltuk. A négy, meteorológiai és növekedési adatok alapján kiválasztott év esetében egyedül a 2015-2016. évi beavatkozásokat követő 2017. során haladta meg a projektterületi állományok átmérőnövedéke a kontroll állományét. A relatív növekedési adatokban bekövetkezett csökkenésben ez szignifikáns különbségnek bizonyult. A változás feltehetően a projekt keretében végrehajtott müszaki beavatkozások kedvező hatását mutatja az érintett állományok növekedésének aszályokkal szembeni stabilitását illetően. A pozitív eredményeket a projektterületi talajvíz-viszonyok kontrollmérésekhez képest megfigyelt javulása is alátámaszztja (Eötvös \& Horváth 2018).

Ugyanakkor, a 2017. évben mind az 5 parcella nagyobb visszaesést mutatott, mint az ez évi modellezett relatív növedék, ami a helyi meteorológiai mérések rácsponti adatokkal való inhomogenitásának lehetséges problémáján túl jelezheti a sorozatos aszályok és a kedvezőtlen éghajlati trendek hatását, még az ezeket mérséklő beavatkozások mellett is. Utóbbi tendenciát a háromévi talajvízmérések alapvetően süllyedő idősorában szintén fel lehet fedezni, noha a kontrollhoz képest a projektterületi adatok jóval kisebb csökkenést mutatnak. Mind az évgyűrü-, mind a talajvízmérések tehát egyelöre inkább a kedvezőtlen folyamatok mérséklését, lassítását, mintsem azok visszafordítását látszanak igazolni. Nem kizárt azonban, hogy a későbbiek folyamán, a további vízvisszatartás (pl. tározók vízszint-szabályozása, illetve a lefektetett mederbordák hordalékkal való feltöltődése) mellett a projekt kedvező hatásai a talajvízgazdálkodásra és ezáltal az élö- és termőhelyre tovább fokozhatók.

Vizsgálataink előzetes jellege, illetve a hidrológiai beavatkozások óta eltelt rövid idő miatt az erdészeti gyakorlat számára levonható következtetések köre igen korlátos. A termőhely hidrológiai viszonyainak jövője további talajvízmérésekkel lehet becsülhető. Az eredmények alátámasztják, hogy az égeresek kedvező növekedésmenete a minél egyenletesebb talajvízellátottság mellett érhető el. A két fafaj változó környezet melletti hosszútávú versenyképessége, és a területre vonatkozó sikeres fafajmegválasztás kérdése további, különböző korosztályokra való vizsgálatok tárgyát képezheti. 


\section{KÖSZÖNETNYILVÁNÍTÁS}

Köszönjük Dr. Szabados Ildikónak a projektfeladat tervét és alapgondolatát és a Kaszó Zrt. munkatársainak, Szalai Kittinek és Horváth Lászlónak a munkánk során nyújtott segítségét és a termőhelyi információk rendelkezésre bocsátását. A kutatás az „Enyves éger (Alnus glutinosa) és magas köris (Fraxinus excelsior) alkotta ligeterdők (Alno-Padion, Alnion incanae, Salicion albae) helyreállitása és megőrzése Kaszó területén" c. projekt (LIFE12 NAT/HU/000593) támogatásával valósul meg.

\section{FELHASZNÁLT IRODALOM}

Árvai M., Morgós A. \& Kern Z. 2018: Growth-climate relations and the enhancement of drought signals in pedunculate oak (Quercus robur L.) tree-ring chronology in Eastern Hungary. iForest-Biogeosciences and Forestry 11: 267-274. DOI: 10.3832/ifor2348-011

Buras A., Schunk C., Zeiträg C., Herrmann C., Kaiser L., Lemme H., Straub C., Taeger S., Gößwein S., Klemmt H-J. \& Menzel A. 2018: Are Scots pine forest edges particularly prone to drought-induced mortality? Environmental Research Letters 13: 025001. DOI: 10.1088/1748-9326/aaa0b4

Čater M. \& Levanič T. 2015: Physiological and growth response of Quercus robur in Slovenia. Dendrobiology 74: 3-12. DOI: 10.12657/denbio.074.001

Claessens H., Oosterbaan A., Savill P. \& Rondeux J. 2010: A review of the characteristics of black alder (Alnus glutinosa (L.) Gaertn.) and their implications for silvicultural practices. Forestry 83: 163-175. DOI: 10.1093/forestry/cpp038

DDKÖVízIG. Dél-dunántúli Környezetvédelmi és Vizzügyi Igazgatóság. 2011: A vízvisszatartás lehetőségeinek vizsgálata a Kaszói Erdőgazdaságban. Müszaki tanulmányterv. Pécs

Eötvös Cs. B. \& Horváth L. 2018: A Szentai-erdö talajvizszint változásai a KASZÓ-LIFE projekt hatására. (poszter). Water in Forests. International Conference of KASZÓ-LIFE project, Kaszó, 2018. május 29-30.

Garamhegyi T., Kovács J., Pongrácz R., Tanos P. \& Hatvani I. G. 2018: Investigation of the climate-driven periodicity of shallow groundwater level fluctuations in a Central-Eastern European agricultural region. Hydrogeology Journal 26: 677-688. DOI: 10.1007/s10040-017-1665-2

Gencsi L. \& Vancsura R. 1992: Dendrológia. Mezőgazda Kiadó, Budapest

Haylock M. R., Hofstra N., Klein Tank A. M. G., Klok E. J., Jones P. D. \& New M. 2008: A European daily highiresolution gridded data set of surface temperature and precipitation for 1950-2006. Journal of Geophysical Research: Atmospheres 113(D20). DOI: 10.1029/2008jd010201

Laganis J., Pečkov A. \& Debeljak M. 2008: Modeling radial growth increment of black alder (Alnus glutionsa (L.) Gaertn.) tree. Ecological Modelling 215: 180-189. DOI: 10.1016/j.ecolmodel.2008.02.018

Levanič T. 1993: Effects of hydromelioration on diameter growth and increment of black alder, ash and oak in Slovene Prekmurje. Zbornik gozdarstva in lesarstva 42: 7-65.

Schneider U., Becker A., Finger P., Meyer-Christoffer A. \& Ziese M. 2015: GPCC Monitoring Product: Near Real-Time Monthly Land-Surface Precipitation from Rain-Gauges based on SYNOP and CLIMAT data. DOI: 10.5676/DWD_ GPCC/MP_M_V5_100

Stojanović D. B., Levanič T., Matović B. \& Orlović S. 2015: Growth decrease and mortality of oak floodplain forests as a response to change of water regime and climate. European Journal of Forest Research 134: 555-567. DOI: 10.1007/ s10342-015-0871-5

Szalai S., Auer I., Hiebl J., Milkovich J., Radim T. Stepanek P., Zahradnicek P., Bihari Z., Lakatos M., Szentimrey T., Limanowka D., Kilar P., Cheval S., Deak Gy., Mihic D., Antolovic I., Mihajlovic V., Nejedlik P., Stastny P., Mikulova K., Nabyvanets I., Skyryk O., Krakovskaya S.,Vogt J., Antofie T. \& Spinoni J. 2013: Climate of the Greater Carpathian Region. Final Technical Report. www.carpatclim-eu.org

Vicente-Serrano S. M., Beguería S. \& López-Moreno J. I. 2010: A multiscalar drought index sensitive to global warming: the standardized precipitation evapotranspiration index. Journal of climate 23: 1696-1718. DOI: 10.1175/2009jcli2909.1 